\title{
Respiratory activity and browning of minimally processed sweet potatoes
}

\author{
Celso L. Moretti; Alessandra L. Araújo; Waldir A. Marouelli; Washington L.C. Silva. \\ Embrapa Hortaliças, C. Postal 218, 70.359-970, Brasília, DF; celso@enph.embrapa.br
}

\begin{abstract}
Sweet potatoes (Ipomoea batatas L.), 'Brazlândia Roxa', 'Brazlândia Branca' and 'Princesa' were harvested at optimum maturity to evaluate respiratory activity and browning susceptibility of minimally processed roots. After harvest, non-blemished roots were graded for size $(18 \pm 2 \mathrm{~cm})$ and diameter $(5 \pm 1 \mathrm{~cm})$, and minimally processed inside a cold room. Processed roots were placed in sealed glass jars and stored at $3 \pm 0.5^{\circ} \mathrm{C}$ to evaluate respiratory activity during a 4-hour period or were packed in plastic films with partial vacuum to evaluate development of browning. Packages were stored under refrigerated conditions $\left(3 \pm 0.5^{\circ} \mathrm{C}\right)$ for 5 days. Daily, minimally processed roots were evaluated for browning according to a scale ranging from 0 (extremely browned) to 5 (no browning) and using an objective assay (absorbance at $340 \mathrm{~nm}$ ). Minimally processed roots showed a pronounced increase in carbon dioxide evolution immediately after processing. 'Princesa' had the highest respiratory activity among the evaluated cultivars, being $40 \%$ higher two hours after processing than the other cultivars. 'Brazlândia Roxa' and 'Brazlândia Branca' were significantly less susceptible to browning compared to 'Princesa', which was rated as unacceptable for commercial use at the end of the storage period. 'Brazlândia Roxa' and 'Brazlândia Branca' were still marketable at the end of the storage period.
\end{abstract}

Keywords: Ipomoea batatas, carbon dioxide, mechanical damage, polyphenoloxidase, postharvest, sensory analysis, storage.

\section{RESUMO}

Atividade respiratória e escurecimento de raízes de batatadoce minimamente processada

Batata doce (Ipomoea batatas L.), 'Brazlândia Roxa', 'Brazlândia Branca' e 'Princesa' foram colhidas no ponto ótimo de maturidade hortícola, com o objetivo de avaliar-se a atividade respiratória e a suscetibilidade ao escurecimento de raízes minimamente processadas. Após a colheita, raízes sem danos mecânicos aparentes foram selecionadas para tamanho $(18 \pm 2 \mathrm{~cm})$ e diâmetro $(5 \pm 1 \mathrm{~cm})$ e foram minimamente processadas no interior de uma câmara fria. As raízes minimamente processadas foram colocadas em frascos de vidro hermeticamente fechados e armazenados a $3 \pm 0,5^{\circ} \mathrm{C}$ para avaliar-se a atividade respiratória durante um período de 4 horas. Porções de raízes minimamente processadas $( \pm 300 \mathrm{~g})$ foram armazenadas em filmes plásticos com vácuo parcial para avaliação do desenvolvimento de escurecimento. As embalagens foram armazenadas sob refrigeração $\left(3 \pm 0,5^{\circ} \mathrm{C}\right)$ por 5 dias. Diariamente, as raízes minimamente processadas foram avaliadas para escurecimento de acordo com uma escala de notas variando de 0 (extremamente escurecido) a 5 (sem escurecimento) e utilizando um método objetivo (absorbância a $340 \mathrm{~nm}$ ). As raízes minimamente processadas apresentaram um aumento pronunciado na atividade respiratória logo após o processamento. A cultivar Princesa apresentou a maior atividade respiratória dentre os materiais estudados, possuindo uma atividade respiratória $40 \%$ superior às demais cultivares, 2 horas após o processamento. As cultivares Brazlândia Roxa e Brazlândia Branca foram significativamente menos suscetíveis ao escurecimento quando comparadas com "Princesa", que possuía qualidade comercial inaceitável ao final do período experimental. Por outro lado, as cultivares Brazlândia Roxa e Brazlândia Branca ainda possuíam qualidade comercial ao final do experimento.

Palavras-chave: Ipomoea batatas, análise sensorial, armazenamento, dióxido de carbono, dano mecânico, polifenoloxidase, pós-colheita.

\section{(Recebido para publicação em 21 de dezembro de 2001 e aceito em 19 de abril de 2002)}

$\mathrm{C}_{\mathrm{r}}$ onsumer demand for fresh-cut products has grown rapidly during the past few years. The foodservice industry has strived to prepare, handle and deliver a fresh, healthy and convenient product to the consumer. Processing freshcut produce involves steps such as cleaning, washing, trimming, coring, slicing, shredding, and other related operations (Cantwell, 2000). The fresh-cut produce business is showing exponential growth in many countries, especially in the vicinity of medium and large metropolitan areas (Moretti et al, 2000). Supermarkets in the Sao Paulo, Brazil area sell around US\$ 4 million of fresh-cut products on a monthly basis, consisting of fruits (54\%) and vegetables (46\%) (Min. Integ. Nac., 1999).

Whereas most food processing techniques lengthen the shelf life of products, minimal processing increases their perishability (Cantwell, 2000). This is primarily due to the occurrence of mechanical damage during the preparation procedures. Mechanical damage can increase carbon dioxide and ethylene evolution (Moretti et al., 1998), increase water loss (Chuma et al., 1984), alter flavor and aroma (Moretti \& Sargent, 2000), and increase the activity of enzymes related to enzymatic browning, e.g. phenylalanine-ammonialyase (PAL) (Ke \& Saltveit, 1989a) and polyphenol oxidase (Bower \& Van Lelyveld, 1985; Nicoli et al., 1994). 
Enzymatic browning is one of the limiting factors affecting the storage of fresh-cut fruit and vegetables (Brecht, 1995). Oxygen, enzyme, metallic ion and substrate are the four basic compounds necessary for the occurrence of enzymatic browning (Whitaker \& Lee, 1995). Browning intensity is affected by factors such as the concentration of substrates and the relative activity of oxidases (Hansche \& Boyton, 1986).

Several techniques, such as the utilization of sulfites, ascorbic acid, surface digestion, heated ascorbic and citric acid solution, have been proposed to overcome browning in fresh-cut products (Sapers \& Miller, 1992; 1993; 1995). The utilization of sulfites has been drastically reduced in the food processing industry worldwide since there is a significant increase in the number of people showing allergic reactions (Willey, 1994). In the United States, fresh consumed products can not be treated with sulfites (FDA, 1996).

Among vegetable crops of economical importance, sweet potato is being minimally processed to supply both the foodservice and the retail sectors, and browning is one of the most important problems processors are experiencing with this crop. Evaluation of cultivars that are less susceptible to browning can be an efficient way to overcome this problem.

Weller et al. (1997) observed significant differences among star fruit cultivars that resulted in the selection of cultivars with reduced browning. Similarly, Ahvenainen \& Hume (1994) and Amiot et al. (1992) showed that choosing the appropriate cultivars of potatoes, carrots, onions, and apples is a factor leading to success in the freshcut business. Mondy \& Mushi (1993) observed that different agronomic practices during the production of potatoes can help overcoming postharvest problems related to enzymatic browning.

The present work was carried out to evaluate respiratory activity and occurrence of browning in three minimally processed sweet potato cultivars.

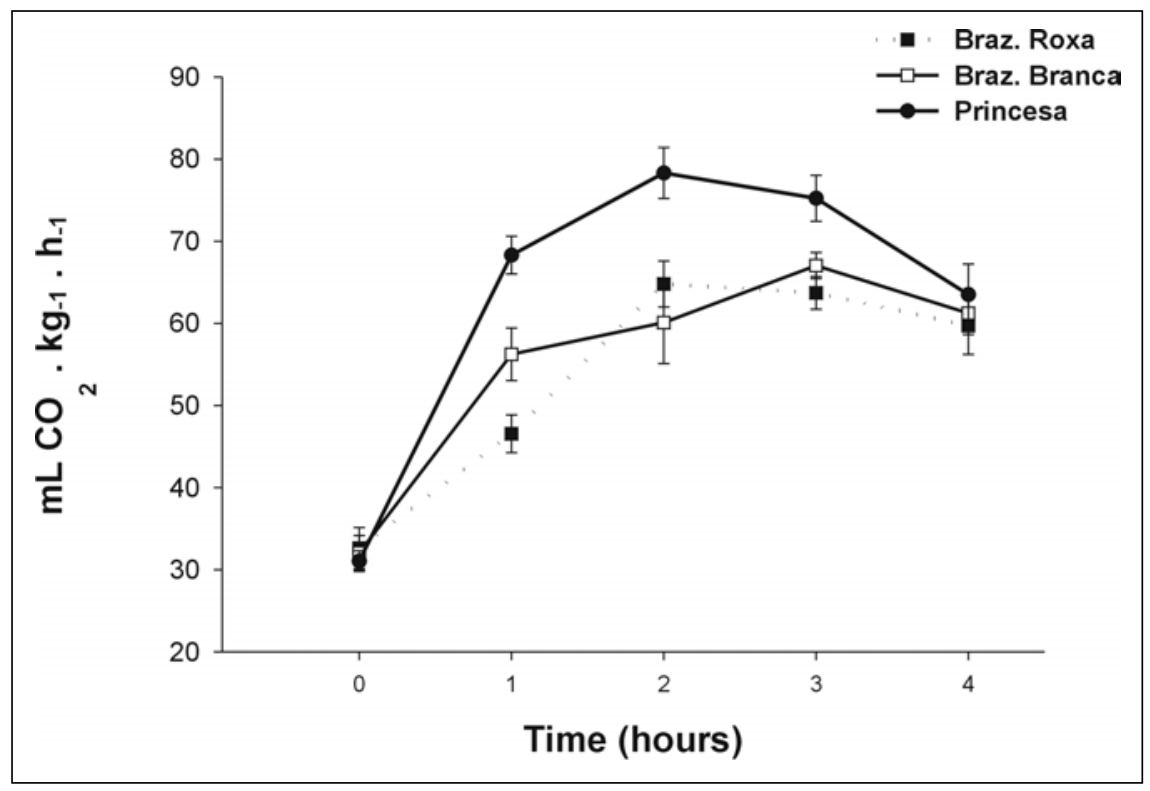

Figure 1. Respiratory activity $\left(\mathrm{mLCO}_{2} \cdot \mathrm{kg}^{-1} \cdot \mathrm{h}^{-1}\right)$ of fresh-cut sweet potatoes stored for 4 hours at $3 \pm 0.5^{\circ} \mathrm{C}$. Vertical bars indicate $\pm \mathrm{SD}$. Brasília, Embrapa Hortaliças, 1999 .

\section{MATERIAL AND METHODS}

\section{Plant material}

Sweet potatoes (Ipomoea batatas L.), 'Brazlândia Roxa', 'Brazlândia Branca' and 'Princesa' were harvested at the optimum maturity stage from fields at Embrapa Hortaliças in February, 1999. After harvest, roots were transported to the postharvest laboratory, and non-blemished roots were graded for size $(18 \pm 2 \mathrm{~cm})$ and diameter $(5 \pm 1 \mathrm{~cm})$, and then were minimally processed inside a cold room $\left(12 \pm 2^{\circ} \mathrm{C}\right)$.

\section{Minimal processing}

Roots of the three cultivars were prewashed in tap water, and then sliced ( $5 \pm 1 \mathrm{~mm}$ thick), rinsed, dipped for 10 minutes in $\mathrm{NaClO}\left(150 \mathrm{mg} \cdot \mathrm{kg}^{-1}\right)$, and centrifuged $(800 \mathrm{~g})$ for 5 minutes.

\section{Respiratory activity}

Two kilograms of minimally processed roots were placed inside each sealed, 3.5 L glass jar and stored at $3{ }^{\circ} \mathrm{C}$. Every hour, during a 4-hour period, air samples were taken from the glass jars. $\mathrm{CO}_{2}$ evolution was measured using a gas chromatograph.

\section{Evaluation of browning}

To evaluate browning, minimally processed roots $(300 \mathrm{~g})$ were wrapped in plastic films (permeability to $\mathrm{O}_{2}=6,000$
$8000 \mathrm{~cm}^{3} \mathrm{~m}^{-2}$ day ${ }^{-1}$; permeability to $\mathrm{CO}_{2}$ $=18,0000-24,000 \mathrm{~cm}^{3} \mathrm{~m}^{-2} \mathrm{day}^{-1}$; permeability to water vapor $=0.90-1.10$ $\mathrm{g} \mathrm{m}^{-2}$ day $^{-1}$ ), partial vacuum was generated, and packages were stored under refrigerated conditions $\left(3^{\circ} \mathrm{C}\right)$ for 5 days. Fresh-cut roots were then evaluated daily for browning using two different methods: sensory and chemical analysis.

\section{Sensory analysis}

Sensory analyses were performed by panelists using an arbitrary scale ranging from 5 to 0 (5-no browning; 4 - slightly browned; 3 - few browning; 2 browned; 1 - very browned; 0 extremely browned). Samples were presented to panelists $(n=35)$ who evaluated browning of roots according to the 5 to 0 scale. The limit for commercial acceptance was set at 3 (few browning).

\section{Chemical analysis}

Chemical analysis was carried out according to Couture et al. (1993). Fresh-cut roots $(20 \mathrm{~g})$ were homogenized in a Polytron (speed 5) for 50 seconds with $20 \mathrm{~mL}$ of deionized water. Homogenate was centrifuged at $5^{\circ} \mathrm{C}(27,600 \mathrm{~g}$ for 15 minutes $)$, and filtered through Whatman paper \#4. Absorbance was read in a spectrophotometer at $340 \mathrm{~nm}$.

\section{Statistical analysis}

Sensory analysis. Analyses were performed using randomized blocks, 


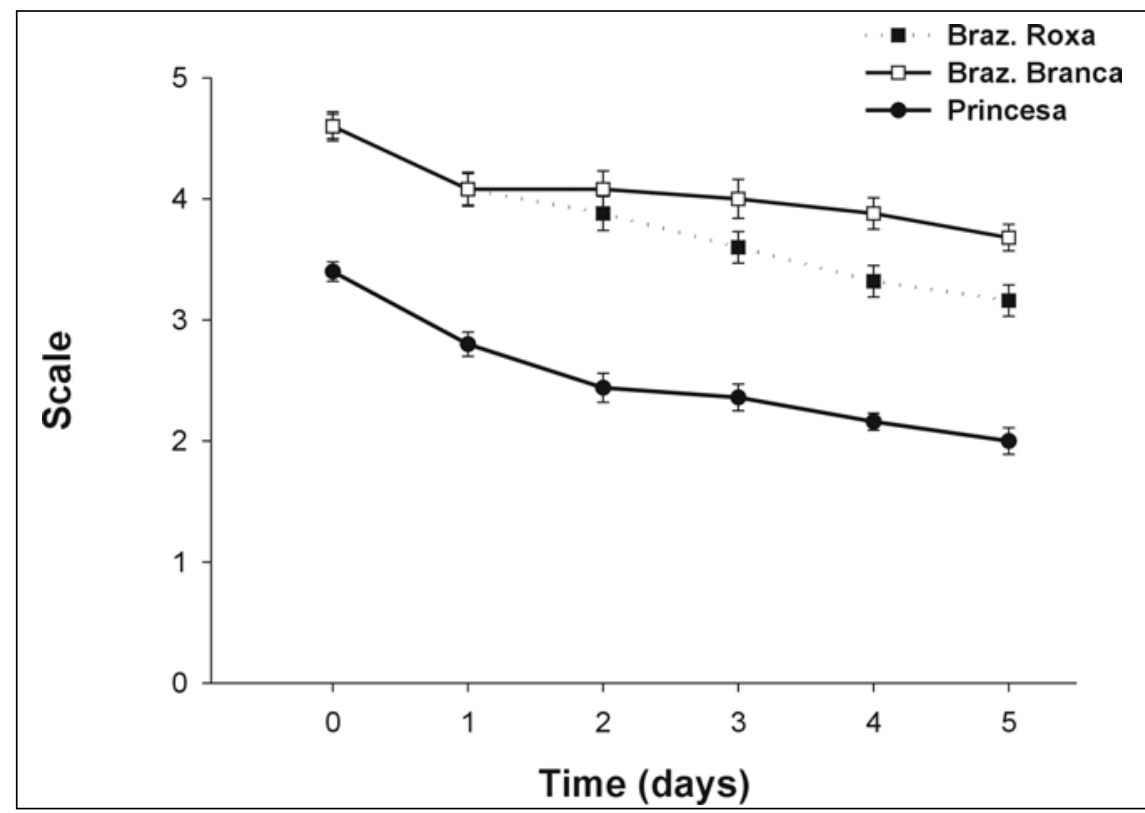

Figure 2. Sensory analysis of fresh-cut sweet potatoes stored for 5 days at $3 \pm 0.5^{\circ} \mathrm{C}$. Arbitrary scale: 5 - no browning; 4 - slightly browned; 3 -few browning; 2 - browned; 1 - very browned; 0 - extremely browned. Vertical bars indicate \pm SD. Brasília, Embrapa Hortaliças, 1999.

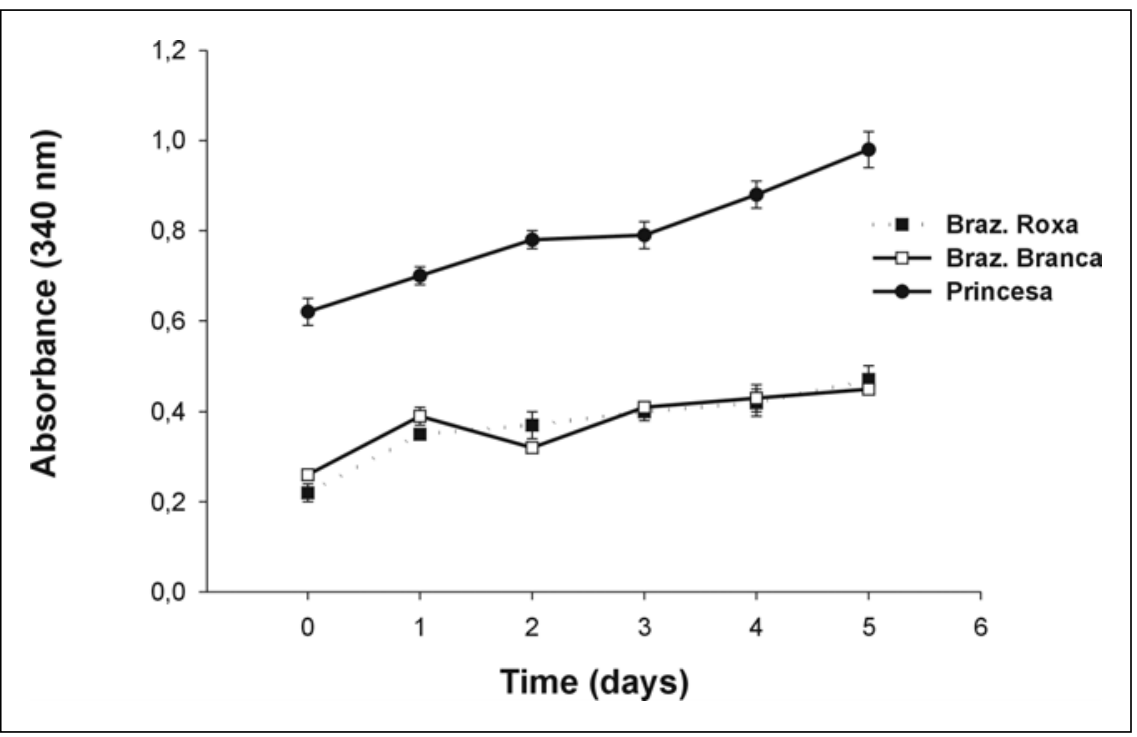

Figura 3. Absorbance $(340 \mathrm{~nm})$ of fresh-cut sweet potatoes stored for 5 days at $3 \pm 0.5^{\circ} \mathrm{C}$. Vertical bars indicate \pm SD. Brasília, Embrapa Hortaliças, 1999.

using panelists' $(\mathrm{n}=35)$ rating as blocks, 15 treatments (3 cultivars and 5 sampling times) arranged in a factorial scheme, and 4 replicates ( 4 packages of $300 \mathrm{~g}$ each). Data were subjected to analysis of variance and the least significant difference procedure was carried out. Differences between any two treatments larger than the sum of two standard deviations were always significant $(\mathrm{P}=0.05)$.

Carbon dioxide and chemical analysis. Analyses were performed using a completely randomized design, with 15 treatments arranged in a factorial scheme ( 3 cultivars and 5 sampling times), and 4 replications (4 jars of $3.5 \mathrm{~L}$ each for carbon dioxide evolution; 4 packages of $300 \mathrm{~g}$ each for browning evaluation). Data were subjected to analysis of variance and the least significance difference procedure was carried out. Differences between any two treatments larger than the sum of two standard deviations were always significant $(\mathrm{P}=0.05)$.

\section{RESULTS AND DISCUSSION}

\section{Carbon dioxide evolution}

Two hours after "Princesa" sweet potatoes were cut, there was a large increase in $\mathrm{CO}_{2}$ evolution. Evolution of $\mathrm{CO}_{2}$ at that point was around $40 \%$ higher than for the two other cultivars (Figure 1). There was a decrease in respiratory activity three hours after processing for "Brazlândia Roxa" and "Brazlândia Branca". A decrease in respiration for "Princesa" occurred two hours after processing. There was no difference among cultivars in carbon dioxide evolution four hours after processing (Figure 1).

The observed increase in respiratory activity of fresh-cut produce is caused by injury incurred during processing procedures. Moretti et al. (2000) observed that minimal processing significantly increased respiratory activity of fresh-cut green bell peppers cv. Magali.

\section{Sensory analysis}

"Brazlândia Roxa" and "Brazlândia Branca" exhibited less browning than "Princesa". Immediately after processing, "Princesa" showed more browning than the other two cultivars (Figure 2). At the fifth day, "Princesa" was rated unmarketable due to its severe browning. "Brazlândia Roxa" and "Brazlândia Branca" still presented rates above 3 (Figure 2).

This suggests that the differences regarding browning in the cultivars studied could be related to intrinsic genetic characteristics as well as to the different patterns of carbon dioxide evolution showed by the three cultivars. Ke \& Saltveit (1989b) showed that increased respiratory activity induces increased PAL activity, thus increasing cinamic acid concentrations and its derivates in the cellular medium. Those substances are metabolized to soluble phenolic compounds, which are used as substrates by polyphenoloxidase to produce brown substances.

\section{Chemical analysis}

As demonstrated by the sensory analysis, "Princesa" developed more browning than the other two cultivars. 
Immediately after processing, "Princesa" had an absorbance that was around three times higher than the other two cultivars (Figure 3). By the fifth day, the absorbance for "Princesa" was 117 and 108\% higher than "Brazlândia Branca" and "Brazlândia Roxa", respectively (Figure 3).

It is believed that the higher absorbance observed for "Princesa" throughout experiment could be related to the fact that this cultivar contains a higher level of phenolic compounds that absorb light at $340 \mathrm{~nm}$.

In summary, the data presented suggest that "Brazlândia Branca" and "Brazlândia Roxa" are more suitable for minimal processing than "Princesa", based on their relative browning susceptibility. Further studies will be conducted to evaluate the cooking behavior of these cultivars.

\section{ACKNOWLEDGEMENTS}

The authors are grateful to Fundação de Apoio a Pesquisa do Distrito Federal (FAP-DF) for the financial support.

\section{LITERATURE CITED}

AHVENAINEN, R.; HUME, E. Minimal processing of vegetables. In: Ahvenainen, R., T. Matilla-Sandholm and T. Olhsson (eds.). Minimal processing of foods. Espoo, Finland, VTT Symposium, v. 142, p. 17-35, 1994.

AMIOT, M.J.; TACCHINI, M.; AUBERT, S.; NICOLAS, J. Phenolic composition and browning susceptibility of various apple cultivars at maturity. Journal of Food Science, v. 57, p. 955-962, 1992.
BOWER, J.P.; VAN LELYVELD, L.J. The effects of stress history and container ventilation on avocado fruits polyphenol oxidase activity. Journal of Horticultural Science, v. 60, p. 545547, 1985.

BRECHT, J.K. Physiology of lightly processed fruits and vegetables. HortScience, v. 30, n. 1, p. 45-46, 1995.

CANTWELL, M.I. Preparation and quality of fresh-cut produce. In: II Encontro Nacional sobre Processamento Minimo de Frutas e Hortaliças. Viçosa, MG. Proceedings.... Viçosa, MG, Brazil, v. 1, p. 156-182, 2000.

CHUMA, Y.; MURATA, S.; IWAMOTO, M.; NISHIHARA, A.; HORI, Y. Donner strawberry transportation in refrigerated truck for 700 kilometers. Annals of Agricultural Engineering Society, v. 45, n. 2, p. 292-297, 1984.

COUTURE, R.; CANTWELL, M.I.; KE, D.; SALTVEIT, JR, M.E. Physiological attributes related to quality attributes and storage life of minimally processed lettuce. HortScience, v. 28, p. 723-725, 1993.

FDA. Chemical preservatives. Food and Drug Administration. Code of Federal Regulations title 21, Part 182, Washington DC, USA; The Office of Federal Register. 1996. 120 p.

HANSCHE, P.E.; BOYTON, B. Heritability of enzymatic browning in peaches. HortScience, v. 21, p. 1195-1197, 1986.

KE, D.; SALTVEIT JR, M.E. Wound induced ethylene production, phenolic metabolism, and susceptibility to russet spotting in iceberg lettuce. Plant Physiology, v. 76, p. 412-418, 1989a.

KE, D.; SALTVEIT JR, M.E. Carbon dioxideinduced brown stain development as related to phenolic metabolism in iceberg lettuce. Journal of the American Society for Horticultural Science, v. 114, n. 4, p. 789-794, 1989b.

MINISTÉRIO DA INTEGRAÇÃO NACIONAL. A importância dos pré-processados. FruitFatos, v. 1, n. 1, p. 16-18, 1999.

MONDY, N.I., MUNSHI, C.B. Effect of type of potassium fertilizer on enzymatic discoloration and phenolic, ascorbic acid and lipid contents of potatoes. Journal of Agriculture and Food Chemistry, v. 41, p. 849-852, 1993.
MORETTI, C.L., SARGENTS. A.; HUBER, D.J.; CALBO, A.G.; PUSCHMANN, R. Chemical composition and physical properties of pericarp, locule and placental tissues of tomatoes with internal bruising. Journal of the American Society for Horticultural Science, v. 123, n. 4, p. 656-60, 1998.

MORETTI, C.L.; SARGENT, S.A. Alteração de aroma e sabor em frutos de tomate com desordem fisiológica causada por impacto. Scientia Agricola v. 57, n. 3, p. 385-388, 2000.

MORETTI, C.L.; SILVA, W.L.C.; ARAÚJO, A.L. Quality attributes and carbon dioxide evolution of bell peppers as affected by minimal processing and storage temperature. Proceedings of the Florida State Horticultural Society, v. 113, p. 156159, 2000.

NICOLI, M.C., ANESE, M.; SEVERINI, C. Combined effects in preventing enzymatic browning reactions in minimally processed fruit. Journal of Food Quality, v. 17, p. 221-29, 1994. SAPERS, G.M.; MILLER, R.L. Enzymatic browning control in potato with ascorbic acid-2phosphates. Journal of Food Science, v. 57, p. 1132-1135, 1992.

SAPERS, G.M.; MILLER, R.L. Control of enzymatic browning in pre-peeled potatoes by surface digestion. Journal of Food Science, v. 58, p. 1076-1078, 1993.

SAPERS, G.M.; MILLER, R.L. Heated ascorbic/ citric acid solution as browning inhibitor for prepeeled potatoes. Journal of Food Science, v. 60, p. 762-766, 1995.

WELLER, A., SIMS, C.A.; MATTHEWS, R.F.; BATES, R.P.; BRECHT, J.K. Browning susceptibility and changes in composition during storage of carambola slices. Journal of Food Science, v. 62, p. 256-260, 1997.

WHITAKER, J.R.; LEE, C.Y. Recent advances in chemistry of enzymatic browning, In: LEE, C.Y.; WHITAKER, J.R. (eds). Enzymatic browning and its prevention. Washington DC: American Chemistry Society, Symposium Series, v. 600, p. 2-7, 1995.

WILEY, R.C. Minimally processed refrigerated fruits and vegetables. New York, Chapman \& Hall, 1994. 368 p. 